\title{
PENGARUH PERBANDINGAN KOSENTRASI GLUKOSA DAN SUKROSA TERHADAP KUALITAS SENSORI DAN KIMIA PERMEN JELLY RUMPUT LAUT (Eucheuma cottonii)
}

The Effect of Comparison of Glucose and Sucrose Concentration on the Sensory and Chemical Quality of Jelly Candy (Eucheuma cottonii)

\author{
Arifi Jaldin ${ }^{1}$, Haslianti ${ }^{1}$, Nur Asyik ${ }^{2}$ \\ ${ }^{1}$ Jurusan Teknologi Hasil Perikanan, Fakultas Perikanan dan Ilmu Kelautan Universitas Halu Oleo, Kendari, \\ Sulawesi Tenggara, Indonesia \\ 2Jurusan IImu dan Teknologi Pangan, Fakultas Pertanian Universitas Halu Oleo, Kendari, Sulawesi Tenggara, \\ Indonesia \\ *Email korespondensi: arifin9597@gmail.com (Telp: +6282296254977) \\ Diterima: 3 Oktober/ Disetujui 25 Oktober 2019
}

Cara sitasi: Jaldin A, Haslianti, Asyik N. 2019. Pengaruh perbandingan kosentrasi glukosa dan sukrosa terhadap kualitas sensori dan kimia permen jelly rumput laut (Eucheuma cottonii). Jurnal Fish Protech. 2(2):234-243.

\section{ABSTRACT}

The aims of this study was to determine the effect of different concentrations of glucose and sucrose on the sensory and chemical quality of seaweed jelly candy (Eucehuma cottonii). The study used a Completely Randomized Design (CRD) consisting of 4 treatments, namely: $P 1$ (glucose : sucrose $=45 \%: 0 \%$ ), P2 (glucose : sucrose $=0 \%: 45 \%, P 3$ (glucose $:$ sucrose $=30 \%: 15 \%), P 4$ (glucose $:$ sucrose $=15 \%: 30 \%$ ) with time three replications. Data from observations were analyzed using ANOVA (Analysis of Variance) at a level of $95 \%$, if there is a real difference ( $P>0.05)$ then a further test was performed with a DMRT (Duncan Multiple Range Test) test at a 95\% significance level. The results obtained show a real effect on sensory values which include color, texture, and taste but no significant effect on the scent. The best results for sensory assessment were found in the P4 treatment which has a taste value of 4.5, texture of 4.2, the scent of 4.0, and taste of 4.2 . The results showed the water content between $22.83 \%-17.01 \%$, ash content of $0.11 \%-0.18 \%$. and protein content of $3.75 \%-5.77 \%$.

Keywords: chemistry, glucose, jelly candy, seaweed (Eucheuma cottonii), sensory, and sucrose

\begin{abstract}
ABSTRAK
Tujuan penelitian ini adalah untuk mengetahui pengaruh perbedaan kosentrasi glukosa dan sukrosa terhadap kualitas sensori dan kimia permen jelly rumput laut (E. cottonii). Penelitian menggunakan Rancangan Acak Lengkap (RAL) yang terdiri dari 4 perlakuan yaitu : P1 (glukosa : sukrosa $=45 \%: 0 \%$ ), P2 (glukosa : sukrosa $=0 \%: 45 \%$ ), P3 (glukosa : sukrosa $=30 \%: 15 \%$ ), P4 (glukosa : sukrosa $=15 \%: 30 \%$ ) dan ulangan sebanyak tiga kali. Data hasil pengamatan dianalisa menggunakan ANOVA (Analysis of Variance) pada taraf $95 \%$, apabila terdapat beda nyata $(\mathrm{P}>0,05)$ maka dilakukan uji lanjut dengan uji DMRT (Duncan Multiple Range Test) pada taraf nyata $95 \%$. Hasil penelitian yang diperoleh menunjukkan pengaruh nyata terhadap nilai sensori yang meliputi warna, tekstur, dan rasa namun diperoleh pengaruh tidak nyata pada aroma. Hasil terbaik untuk penilaian sensori terdapat pada perlakuan P4 yaitu memiliki nilai rasa 4,5, tekstur 4,2, aroma 4,0, dan rasa 4,2. Hasil penelitian menunjukkan kadar air antara 22,83\%$17,01 \%$, kadar abu $0,11 \%-0,18 \%$. dan kadar protein $3,75 \%-5,77 \%$..
\end{abstract}

Kata kunci: glukosa, kimia, permen jelly, rumput laut (Eucheuma cottonii), sensori, sukros

\section{PENDAHULUAN}

Rumput laut (Eucheuma cottonii) merupakan yang sangat tinggi di Indonesia. Pengembangan dan bahan pangan lokal yang mempunyai ketersediaan pembudidayaan rumput laut di Sulawesi Tenggara 
cukup berkembang karena didukung oleh potensi sumber daya pesisir yang cukup baik untuk pengembangan rumput laut. Produksi perikanan budidaya rumput laut menurun dari 917.363 ton tahun 2013 menjadi 956.017 ton pada tahun 2014, dan penurunan produksi lebih tinggi terjadi pada tahun 2015 yakni hanya mencapai 915.895 ton (BPS, 2016).

Pemanfaatan rumput laut masih sangat rendah karena sampai saat ini mayoritas masyarakat hanya memanfaatkannya dalam bentuk rumput laut kering. Rumput laut akan memiliki nilai jual lebih tinggi jika diolah menjadi produk agar-agar, karaginan, dan alginat serta produk pangan siap konsumsi (DKP, 2006). Berdasarkan hal tersebut, maka perlu adanya pengembangan produk berbasis rumput laut. Salah satu produk olahan yang dapat meningkatkan nilai tambah rumput laut adalah permen jelly rumput laut.

Permen jelly rumput laut merupakan salah satu pemanfaatan rumput laut dalam bidang industri berbentuk sejenis permen yang pada umumnya berbahan dasar sukrosa, air, dan glukosa. Gula sangat berpengaruh terhadap pembuatan permen jelly karena dapat berperan sebagai bahan penstabil, gula (sukrosa dan glukosa) pada pembuatan permen dapat meningkatkan intensitas rasa manis. Menurut Lestariani (2008) glukosa memberikan tekstur yang plastis dan dapat mencegah terbentuknya kristal gula. Wahyudi (2003) dalam Lestariani (2008) bahwa gula sukrosa berfungsi sebagai pemanis, pembentuk tekstur, pengawet, pembentuk cita rasa, sebagai substrat bagi mikroba dalam proses fermentasi, bahan pengisi dan pelarut. Penelitian tentang permen jelly rumput laut yang telah dilakukan oleh Putri et al. (2015) tentang pengaruh jenis gula yang berbeda terhadap mutu permen Jelly rumput laut menunjukan hasil uji organoleptik pada perlakuan terbaik penambahan (gula sukrosa) lebih disukai dengan nilai rasa sebesar $80 \%$, warna $100 \%$, dan tekstur $85 \%$, dengan rasa

\section{Rancangan Penelitian}

Penelitian menggunakan Rancangan Acak Lengkap (RAL) yang terdiri dari 4 perlakuan yaitu P1 (Rumput laut 30\% : glukosa $45 \%$ : sukrosa 0\% : air 25\%), P2 (Rumput laut 30\% : glukosa 0\% : sukrosa $45 \%$ : air 25\%), P3 (Rumput laut $30 \%$ : glukosa 30\% : manis dan sedikit keasaman, Penelitian Estherella et al. (2018) menghasilkan nilai rata-rata mutu kadar air sebesar 14,32 \%, kadar abu sebesar 0,11\%, karbohidrat sebesar $75,38 \%$, gula total sebesar 55,22 $\%$. Bahan utama yang digunakan dalam pembuatan permen jelly pada penelitian ini adalah rumput laut $(E$. cottonii). Oleh karena itu perlu dilakukan diversifikasi permen jelly rumput laut dengan menambahkan glukosa dan sukrosa untuk meningkatkan nilai gizi produk rumput laut.

\section{METODE PENELITIAN}

\section{Alat dan Bahan}

Alat yang digunakan dalam penelitian ini ada dua macam yaitu alat untuk pengolahan dan alat untuk analisis. Alat pengolahan meliputi: baskom (planet), pisau (stainless steel), talenan (nampang segi), gelas ukur (herma), blender (Miyako), stopwatch, cetakan (stainless steel), thermometer (torbalscale), panci, dan kompor gas (TOP). Alat untuk analisis kimia meliputi: tabung reaksi, cawan porselin (haldenwanger), vortex (Thermo Maxi), timbangan analitik (torbalscale), hotplate, gelas piala, batang pengaduk, pipet tetes, pipet mikro (toppette P20), oven (memmert), desikator (normax), corong, tabung reaksi, labu takar, erlenmeyer (iwaki), kjedhal, tanur (Furnace D550), bunsen dan alat destilasi.

Bahan baku yang digunakan pada penelitian ini adalah rumput (E. cottonii) kering yang diambil dari perairan Buton Tengah desa Balo Bone. Bahan tambahan yang digunakan adalah glukosa, sukrosa dan air bersih, cucian beras, dan air hujan, akuades, $\mathrm{N}$-ammonia-kloroform, larutan Besi (III) klorida $1 \%$, $\mathrm{K}_{2} \mathrm{SO}_{4}$, asam sulfat, $\mathrm{H}_{2} \mathrm{SO}_{4} 15 \%, \mathrm{NaOH}, \mathrm{Na}_{2} \mathrm{~S}_{2} \mathrm{O}_{3}, \mathrm{NH}_{3}$, alkohol, $\mathrm{FeCl}_{3} \mathrm{0,1 \%}, \mathrm{HCl}, \mathrm{HgO}, \mathrm{H}_{3} \mathrm{BO}_{3}$, Etanol, $\mathrm{Na}-$ thiosulfat $0,1 \mathrm{~N}$ dan minyak zaitun.

sukrosa 15\% : air 25\%), dan P4 (Rumput laut 30\% : glukosa $15 \%$ : sukrosa $30 \%$ : air $25 \%$ ). Setiap perlakuan diulang sebanyak 3 kali sehingga jumlah satuan diperoleh pada percobaan penelitian ini adalah 12 unit percobaan. 


\section{Prosedur Penelitian}

\section{Preparasi Rumput Laut}

Pertama rumput laut dipreparasi dengan perendaman air cucian beras selama 24 jam dan air hujan selama 24 jam. Lalu rumput laut dibersihkan 2 kali dan tiriskan. Setelah ditiriskan rumput laut ditimbang sebanyak $600 \mathrm{~g}$. Kemudian dipotong kecilkecil dan diblender sampai halus (tambahkan air masak $\pm 1,5$ liter). Selanjutnya, dipindahkan ke panci dan dipanaskan dengan suhu $90^{\circ} \mathrm{C}$ selama \pm 80 menit, sambil aduk hingga mengental hingga berbentuk ekstrak rumput laut (E. cottonii). Selanjutnya, ekstrak rumput laut diuji di Laboratorium

\section{Pembuatan Permen Jelly Rumput Laut}

Kedua ekstrak rumput laut (E. cottonii) sebanyak $100 \mathrm{~g}$ dilarutkan kedalam air hangat dengan suhu berkisar $45^{\circ} \mathrm{C}$ sebanyak $\pm 10 \mathrm{ml}$ sambil diaduk hingga homogen lalu ditambahkan glukosa dan sukrosa (sesuai masing-masing perlakuan). Kemudian dilakukan pemasakan dengan suhu $80-100{ }^{\circ} \mathrm{C}$ selama \pm 25 menit lalu adonan yang telah mengental dituang kedalam wadah pencetakan dan didinginkan selama
15 menit pada suhu ruang. Kemudian adonan dipotong-potong sebesar $2 \times 2 \mathrm{~cm}$. Setelah dipotongpotong, hasil berupa permen jelly. Terakhir permen Jelly dianalisis di Laboratorium.

\section{Parameter Uji}

Uji fitokimia (Harbone, 1987) yang dilakukan meliputi uji alkaloid dengan Dragendorf, uji saponin dengan uji busa, uji tanin dengan pereaksi $\mathrm{FeCl}$, dan uji Fenol dengan pereaksi $\mathrm{FeCl}$. Uji sensori (SNI, 2011). yang dilakukan meliputi warna, tekstur, aroma, dan rasa. Uji kimia yang dilakukan meliputi kadar air (AOAC, 2005), kadar abu $(A O A C, 1995)$ dan kadar protein (AOAC,1995).

\section{Analisis Data}

Analisis data yang digunakan dalam penelitian ini adalah dengan menggunakan sidik ragam Analysis of Varian (ANOVA) dan jika hasil analisa terdapat perbedaan nyata, maka akan dilanjutkan dengan uji lanjut Duncan's Multiple Range Test (DMRT) pada taraf kepercayaan $95 \%(a=0,05)$.

\section{HASIL DAN PEMBAHASAN}

\section{Uji Fitokimia Rumput Laut (E. cottonii)}

Tabel 1. Hasil analisis uji sensori

\begin{tabular}{cccc}
\hline No. & Uji Fitokimia & Hasil Uji & Hasil Uji Positif (Harbone, 1987) \\
\hline 1. & Alkaloid & + & Endapan merah \\
2. & Saponin & + & Terbentuk buih \\
3. & Tanin & - & Berwarna merah / biru tua / hijau kehitaman \\
4. & Fenol & - & Berwarna hijau / hijau biru kehitaman \\
\hline
\end{tabular}

Keterangan: + = ada, - = tidak ada

Uji fitokimia rumput laut menunjukkan adanya senyawa alkaloid $(+)$ dan saponin $(+)$ (Tabel 1). Berdasarkan hasil tersebut pada alkaloid dengan pereaksi dragendorf didapatkan adanya alkaloid dalam rumput laut ( $E$. cottonii) yaitu ditandai dengan perubahan larutan yang terbentuknya endapan merah. Penelitian ini sesuai dengan penelitian Yuniarti (2011) yaitu adanya senyawa alkaloid pada rumput laut ( $E$. cottonii). Hal ini disebabkan terjadinya reaksi antara atom nitrogen pada senyawa alkaloid dengan logam yang terkandung dalam pereaksi-pereaksi tersebut membentuk senyawa kompleks. Kelarutan dan sifat lain alkaloid sangat berbeda, cara penjaringan umum untuk alkaloid dalam tumbuhan tidak akan berhasil mendeteksi senyawa khas. Menurut Khunaifi (2010) mekanisme alkaloid dengan cara mengganggu komponen penyusun peptidoglikan pada sel bakteri, sehingga lapisan dinding sel tidak terbentuk secara 
utuh dan menyebabkan kematian sel. Selain itu, biasanya alkaloid diketahui sebagai garam organik dalam tumbuhan dalam berbentuk kristal dan tidak berwarna. Alkaloid memiliki efek dalam bidang kesehatan sebagai pemiccu sistem saraf, menaikkan tekanan darah, mengurangi rasa sakit dan anti mikroba. Selanjutnya, uji fitokimia terhadap saponin dengan uji busa didapatkan adanya saponin dalam rumput laut (E. cottonii) yaitu ditandai dengan perubahan larutan yang terbentuknya buih. Penelitian ini seseuai dengan penelitian Mayore et al. (2018). yaitu adanya senyawa saponin pada rumput laut $(E$. cottonii). Hal ini menandakan bahwa dalam rumput laut ( $E$. cottonii) mengandung senyawa saponin. Menurut Rusyid dan Marina et al. (1990) dalam Sari et al. (2015) menyatakan bahwa busa yang terdapat dalam pengujian senyawa saponin menunjukkan adanya glikosida yang mampu membentuk buih dalam air, senyawa glikosida terhidrolisis menjadi glukosa dan aglikon. Saponin sendiri merupakan senyawa glikosida yang termasuk kelompok aglikon. Glikosida saponin adalah glikosida yang aglikonnya berupa sapogenin (Cheek, 2005) dalam Sari et al., 2015). Mekanisme kerja senyawa saponin yaitu dengan cara mengganggu permeabilitas sel yang menyebabkan senyawa intraseluler seperti sitoplasma akan keluar dan mengakibatkan kematian sel. Hal tersebut diperkuat oleh Nuria et al. (2009), bahwa mekanisme kerja saponin sebagai antibakteri adalah menurunkan tegangan permukaan sehingga mengakibatkan naiknya permeabilitas atau kebocoran sel dan mengakibatkan senyawa intraseluler akan keluar.

\section{Kualitas Sensori Permen Jelly Rumput Laut (E. cottonii)}

Analisis sensori (hedonik) yang dilakukan meliputi parameter warna, tekstur, aroma dan rasa yang dinilai dengan menggunakan kepekaan indra.

Tabel 2. Uji hedonik permen jelly rumput laut

\begin{tabular}{ccccc}
\hline Perlakuan & Warna \pm SD & Tekstur \pm SD & Aroma \pm SD & Rasa \pm SD \\
\hline P1 & $3,9^{\mathrm{a}} \pm 0,2$ & $3,9^{\mathrm{a}} \pm 0,1$ & $3,7 \pm 0,2$ & $3,5^{\mathrm{a}} \pm 0,5$ \\
P2 & $4,0^{\mathrm{ab}} \pm 0,2$ & $4,0^{\mathrm{ab}} \pm 0,2$ & $3,8 \pm 0,1$ & $4,0^{\mathrm{b}} \pm 0,2$ \\
P3 & $4,2^{\mathrm{bc}} \pm 0,3$ & $4,1 \mathrm{abc} \pm 0,1$ & $3,9 \pm 0,2$ & $4,1^{\mathrm{bc}} \pm 0,2$ \\
P4 & $4,5^{\mathrm{cd}} \pm 0,2$ & $4,2^{\mathrm{bcd}} \pm 0,1$ & $4,0 \pm 0,1$ & $4,2^{\mathrm{bcd}} \pm 0,1$
\end{tabular}

Ket : Angka-angka yang diikuti dengan notasi huruf yang sama menunjukkan berbeda tidak nyata berdasarkan uji DMRT0.05 taraf kepercayaan 95\%, SD : standar deviasi.

\section{Warna Permen Jelly Rumput Laut (E. cottonii)}

Penilaian rerata panelis terhadap warna permen jelly rumput laut berkisar antara 3,9-4,5 (Tabel 2). Nilai tertinggi warna permen jelly rumput laut terdapat pada perbandingan kosentrasi glukosa $15 \%$ dan sukrosa $30 \%$ (P4) menunjukan nilai sebesar 4,5 berada pada kategori sangat suka. Hal ini menunjukkan bahwa kombinasi penambahan glukosa yang rendah dan sukrosa yang tinggi dapat menghasilkan warna yang semakin bagus (coklat kuning jernih). Menurut Smith (1991) dalam Hakim (2000) warna coklat terjadi karena adanya pigmen melanoidin yang membentuk warna coklat pada bahan pangan yang dimasak. Hasil tersebut sesuai dengan penelitian Rofiah (2014) bahwa perlakuan tertinggi terdapat pada perlakuan dosis sukrosa 125 gram dan dosis sirup glukosa 40 gram dengan nilai sebesar 3,43. Selanjutnya perlakuan perbandingan kosentrasi glukosa $45 \%$ dan sukrosa $0 \%$ (P1) didapatkan nilai terendah dengan nilai sebesar 3,9 dan berkategori suka tetapi banyak tidak disukai oleh panelis. Menurut Rofiah (2014) warna permen jelly dihasilkan dari adanya pengaruh interaksi antara gula dan pemanasan, dimana dosis sukrosa dan sirup glukosa yang berbeda-beda setiap perlakuan menghasilkan proses inverse sukrosa yang berbeda pula sehingga mempengaruhi warna yang berbeda pada produk yang dihasilkan. Rendahnya nilai warna (P1) disebabkan karena penambahan glukosa yang sangat tinggi dapat memberikan warna yang putih jernih, sehingga dari hasil ini dapat 
diketahui bahwa permen jelly semakin berwarna putih jernih maka panelis semakin tidak menyukainya. Warna permen jelly secara umum mempunyai kriteria normal yang dapat diterima (SNI, 2008) serta memenuhi persyaratan mutu dan kemanan pangan untuk nilai sensori permen jelly maksimal 5 .

\section{Tekstur Permen Jelly Rumput Laut (E. cottonii)}

Penilaian rerata panelis terhadap tekstur permen jelly rumput laut berkisar antara 3,9-4,2 (Tabel 2). Nilai tertinggi tekstur permen jelly rumput untuk perlakuan perbandingan kosentrasi glukosa $15 \%$ dan sukrosa $30 \%$ (P4) menunjukkan nilai sebesar 4,2 berada pada kategori suka. Hal ini menunjukan bahwa pemberian kombinasi penambahan glukosa yang rendah dan sukrosa yang tinggi dapat menghasilkan tekstur yang semakin bagus (tidak terlalu lembek dan elastis). Hasil tersebut sesuai dengan penelitian Rofiah (2014) bahwa perlakuan tertinggi terdapat pada perlakuan dosis sukrosa 100 gram dan dosis sirup glukosa 30 gram dengan nilai sebesar 3,73. Selanjutnya perlakuan perbandingan kosentrasi glukosa $45 \%$ dan sukrosa $0 \%$ (P1) didapatkan nilai terendah dengan nilai sebesar 3,9 berkategori suka tetapi tidak banyak disukai oleh panelis. Rendahnya nilai tekstur disebabkan oleh penambahan hanya glukosa yang tinggi, seperti perlakuan P1, dimana hanya ditambahkan glukosa $45 \%$ saja (tidak ditambahan sukrosa sama sekali). Menurut Mandei (2014) bahwa nilai kesukaan panelis terhadap tekstur dari permen cenderung makin menurun dengan makin banyaknya jumlah gula (glukosa) yang digunakan. Selain itu lama penyimpanan dapat mengurangi kualitas tekstur permen jelly. Menurut Khordi (2010) produk gel yang disimpan pada suhu rendah seperti jelly memerlukan sifat kekuatan gel tinggi dan sineresis rendah karena sineresis yang tinggi pada produk gel akan menyebabkan gel menjadi mengkerut atau kering selama penyimpanan. Tekstur permen jelly secara umum mempunyai kriteria normal yang diterima (SNI, 2008) serta memenuhi persyaratan mutu dan kemanan pangan nilai sensori permen jelly rumput laut yaitu maksimal 5 .

\section{Aroma Permen Jelly Rumput Laut (E. cottonii)}

Penilaian rerata panelis terhadap aroma permen jelly rumput laut berkisar antara 3,7-4,0 (Tabel 2). Nilai tertinggi aroma permen jelly rumput untuk perlakuan perbandingan kosentrasi glukosa 15\% dan sukrosa $30 \%$ (P4) menunjukkan nilai sebesar 4,0 berada pada kategori suka. Hal ini menunjukan bahwa pemberian kombinasi penambahan glukosa yang rendah dan sukrosa yang tinggi dengan pemanasan yang tepat dapat menghasilkan aroma yang semakin bagus (aroma karamel). Hasil tersebut sesuai dengan penelitian Rofiah (2014) bahwa perlakuan tertinggi terdapat pada perlakuan dosis sukrosa 100 gram dan dosis sirup glukosa 40 gram sebesar 3,43. Menurut Rofiah (2014) reaksi karamelisasi timbul karena pemanasan gula dan karamelisasi yang menghasilkan aroma khas karamel. Selanjutnya perlakuan perbandingan kosentrasi glukosa $45 \%$ dan sukrosa $0 \%$ (P1) didapatkan nilai terendah dengan nilai sebesar 3,7 dengan kategori suka tetapi tidak banyak disukai oleh panelis. Berdasarkan hasil rerata tersebut menunjukkan semakin tingginya glukosa dapat menurunkan kesukaan panelis. Menurut Rofiah (2014) terdapat kecenderungan penurunan aroma permen dengan semakin tingginya dosis glukosa yang ditambahkan. Selain itu pencucian dan perendaman rumput laut kurang sesuai dengan penelitian sebelumnya dapat menurunkan aroma permen jelly. Hasil tersebut sesuai dengan pernyataan Yunizal (1999) bahwa tujuan pencucian dan perendaman adalah untuk menghilangkan bau amis dari rumput laut yang digunakan. Xiren and Aminah (2014) menyatakan bahwa penyebab bau amis adalah kandungan amina yang terdapat dalam rumput laut. Aroma permen jelly secara umum mempunyai kriteria normal yang dapat diterima (SNI, 2008) serta memenuhi persyaratan mutu dan kemanan pangan untuk nilai sensori permen jelly rumput laut yaitu maksimal 5.

\section{Rasa Permen Jelly Rumput Laut (E. cottonii)}

Penilaian rerata panelis terhadap rasa permen jelly rumput laut berkisar antara 3,5-4,2 (Tabel 2). Nilai tertinggi rasa permen jelly rumput untuk perlakuan 
perbandingan kosentrasi glukosa $15 \%$ dan sukrosa $30 \%$ (P4) menunjukkan nilai sebesar 4,2 berada pada kategori suka. Tingginya nilai rasa disebabkan karena penerimaan panelis terhadap nilai rasa pada penambahan permen jelly yang tinggi disebabkan karena rasa glukosa dan sukrosa lebih dominan. Hasil tersebut sesuai dengan pernyataan Winarno (1997) bahwa glukosa dan sukrosa dapat meningkatkan citarasa pada bahan pangan. Penambahan glukosa dan sukrosa yang digunakan sebagai bahan dapat memberikan rasa manis dalam permen jelly rumput laut, semakin banyak glukosa dan sukrosa yang ditambahkan maka rasa permen jelly rumput laut ( $E$. cottonii) semakin manis dan tidak memberikan rasa pahit sedikitpun. Selanjutnya perlakuan perbandingan kosentrasi glukosa $45 \%$ dan sukrosa $0 \%$ menunjukkan P1 didapatkan nilai terendah dengan nilai sebesar 3,5. Rendahnya nilai tekstur disebabkan rasa manis dari permen jelly yang makin berkurang dengan makin kurangnya glukosa dan sukrosa yang digunakan karena terhidrolisa. Hasil tersebut sesuai dengan pernyataan Mandei (2014) bahwa makin banyak sukrosa yang digunakan dalam pembuatan permen, makin banyak sukrosa yang terhidrolisa menghasilkan gula invert (campuran glukosa dan sukrosa) yang tingkat kemanisan relatifnya lebih rendah dan dimana makin banyak jumlah gula (sukrosa) yang digunakan, makin banyak sukrosa yang mengalami inversi karena kandungan rumput laut, sehingga kadar sukrosa permen menurun dan tingkat kemanisan dari permen makin menurun. Berdasarkan uji fitokmia bahan dasar pada rumput laut (E. cottonii) yang digunakan dalam pembuatan permen jelly menunjukkan adanya alkaloid dan saponin namun tidak memberikan rasa secara signifikan terhadap rasa permen jelly. Alkaloid dan saponin sampai saat ini diketahui memiliki rasa pahit pada suatu bahan pangan. Alkaloid biasanya terasa pahit (Meyer et al., 1982), selain itu menurut Yanuartono et al. (2017) rasa pada saponin menurunkan palatabilitas dan konsemen. Rasa permen jelly secara umum mempunyai kriteria normal yang dapat diterima (SNI, 2008) serta memenuhi persyaratan mutu dan kemanan pangan untuk nilai sensori permen jelly rumput laut yaitu maksimal 5 .

\section{Kualitas Kimia Permen Jelly Rumput Laut (E. cottonii)}

Tabel 3. Komposisi kimia permen jelly rumput laut berdasarkan metode indeks efektifitas

\begin{tabular}{cccc}
\hline Perlakuan & \multicolumn{3}{c}{ Parameter } \\
\cline { 2 - 4 } & Air (\%) & Abu $(\%)$ & Protein $(\%)$ \\
\hline P1 & 17,01 & 0,11 & 3,75 \\
P2 & 22,83 & 0,12 & 4,00 \\
P3 & 19,41 & 0,18 & 5,13 \\
P4 & 19,10 & 0,12 & 5,77
\end{tabular}

Ket : P1 (Rumput Laut 30\% : Glukosa 45\% : Sukrosa 0\% : Air 25\%), P2 (Rumput Laut 30\% : Glukosa 0\% : Sukrosa 45\% : Air 25\%), P3 (Rumput Laut 30\% : Glukosa 30\% : Sukrosa 15\% : Air 25\%), P4 (Rumput Laut 30\% : Glukosa 15\% : Sukrosa 30\%: Air 25\%).

\section{Kadar Air Permen Jelly Rumput Laut (E. cottonii)}

Nilai kadar air berdasarkan pemilihan perlakuan terbaik metode indeks efektifitas, berkisar antara 22,83\%-17,01\% (Tabel 3). Hasil kadar air permen jelly untuk perlakuan perbandingan kosentrasi glukosa $0 \%$ dan sukrosa 45\% (P2) menunjukkan nilai tertinggi sebesar $22,83 \%$. Tingginya nilai kadar air permen jelly rumput laut disebabkan karena kadar air permen jelly ditentukan oleh kadar air bahan tambahan sukrosa. Hasil tersebut sesuai dengan pernyataan Jumri et al. (2015) kadar air suatu produk ditentukan oleh kadar air bahan baku, bahan pengikat 
yang digunakan dan proses pemasakan. Rahmi et al. (2012) menyatakan bahwa substansi pada bahan terlalu banyak mengandung air atau padatan terlarutnya terlalu rendah sehingga konsistensinya tidak begitu kuat. Konsistensi pembentuk gel yang terlalu sedikit menyebabkan jaringan tidak kuat menahan cairan gula sehingga menyebabkan permen jelly mengalami sineresis dan menghasilkan kadar air yang tinggi (Idham et al., 2018). Selanjutnya perlakuan perbandingan kosentrasi glukosa $45 \%$ dan sukrosa $0 \%$ (P2) didapatkan nilai terendah dengan nilai sebesar $17,01 \%$. Rendahnya nilai kadar air disebabkan karena glukosa sehingga kadar air yang rendah dikarenakan bahan pemanis tersebut menyerap dan mengikat air pada produk permen jelly yang dapat menurunkan kandungan air dalam produk permen jelly. Hasil tersebut sesuai dengan pernyataan Salamah et al. (2006) bahwa kadar air yang tinggi diduga karena jumlah gula yang ditambahkan relative rendah sehingga mengurangi kemampuan penyerapan dan pengikatan air pada produk yang menyebabkan kenaikan kadar air. Berdasarkan uji fitokmia bahan dasar pada rumput laut ( $E$. cottonii) yang digunakan dalam pembuatan permen jelly menunjukkan adanya senyawa alkaloid dan saponin dalam rumput laut, maka kadar air permen jelly terpengaruhi secara spontan karena, pada umumnya alkaloid larut dalam pelarut namun ada beberapa yang larut dalam air seperti Pseudoalkaloid dan protoalkaloid, garam alkaloid, alkaloid quartener sangat larut dalam air (Sastrohamidjojo, 1996), dan saponin larut dalam pelarut polar seperti air (Supriyanto et al., 2017) kadar air permen jelly secara umum mempunyai nilai $20 \%$ yang dapat diterima (SNI, 2008), sehingga pada perlakuan $P 1, P 3$, dan P4 telah sesuai dengan standar SNI 3547.2-2008, tentang syarat mutu permen Jelly, sedangakn pada perlakuan P2 belum sesuai dengan standar SNI 3547.2-2008.

\section{Kadar Abu Permen Jelly Rumput Laut (E. cottonii)}

Nilai kadar abu berdasarkan pemilihan perlakuan terbaik metode indeks efektifitas, berkisar antara 0,11\%-0,18\% (Tabel 3). Hasil kadar abu permen jelly untuk perlakuan perbandingan kosentrasi glukosa $30 \%$ dan sukrosa $15 \%$ menunjukkan tingginya nilai $\mathrm{P} 3$ sebesar $0,18 \%$. Tingginya nilai kadar abu permen jelly rumput laut disebabkan karena sukrosa dan mineral dari rumput laut sehingga mempengaruhi kadar abu produk permen jelly. Hasil tersebut sesuai dengan pernyataan Nurwati (2011) bahwa bahan baku permen seperti gula sukrosa berpengaruh terhadap kadar abu dari permen yang dihasilkan, selain itu didukung oleh pernyataan Ferdin et al. (2019) menyatakan bahwa rumput laut merupakan tanaman yang memiliki mineral makro yaitu kalsium sebesar 186,00 ppm dan fosfor sebesar 2,76 ppm. Kadar abu permen jelly hasil penelitian ini lebih tinggi dari kadar abu tertinggi permen jelly hasil penelitian Salamah et al. (2006) yaitu sebesar 0,03\%. Selanjutnya perlakuan perbandingan kosentrasi glukosa $45 \%$ dan sukrosa 0\% (P1) didapatkan nilai terendah dengan nilai sebesar $0,11 \%$. Rendahnya kadar abu disebabkan karena kandungan abu terhadap glukosa dan sukrosa sangat sedikit. Hasil tersebut sesuai dengan pernyataan Panggalih (2010) bahwa semakin rendah nilai kadar abu maka kandungan mineral pada bahan semakin sedikit. Hal ini berarti bahwa gula yang digunakan memiliki kandungan abu yang lebih rendah dari pada glukosa dan sukrosa. Munurut Mandei (2014) kandungan abu dari glukosa lebih rendah dari sukrosa. Berdasarkan uji fitokimia bahan dasar pada rumput laut (E. cottonii) yang digunakan dalam pembuatan permen jelly menunjukkan adanya senyawa alkaloid dan saponin, maka diduga dari hal tersebut meneral dalam kadar abu permen jelly terpengaruhi secara spontan. Menurut Yanuartono et al. (2017) bahwa saponin dapat mengganggu penyerapan mineral, sedangkan alkaloid tidak diketahui terpengaruh dalam kadar abu permen jelly karena alkaloid larut dalam kadar air. Kadar air permen jelly secara umum mempunyai nilai $3 \%$ yang dapat diterima (SNI, 2008), sehingga pada semua perlakuan sesuai dengan standar SNI 3547.22008. 


\section{Kadar Protein Permen Jelly Rumput Laut (E.} cottonii)

Nilai kadar protein berdasarkan pemilihan perlakuan terbaik metode indeks efektifitas, berkisar antara 3,75\%-5,77\% (Tabel 3). Hasil kadar protein permen jelly untuk perlakuan perbandingan kosentrasi glukosa $15 \%$ dan sukrosa $30 \%$ (P4) menunjukkan nilai tertinggi dengan nilai sebesar $5,77 \%$. Tingginya nilai kadar protein permen jelly rumput laut disebabkan karena proporsi rumput laut yang tinggi sehingga mampu meningkatkan kadar protein pada permen jelly. Secara umum dapat dilihat bahwa dari semua perlakuan cenderung memiliki nilai kadar protein yang mengalami peningkatan seiring dengan kurangnya penambahan perbandingan kosentrasi glukosa dan sukrosa, hal ini dikarenakan rumput laut mengandung protein sehingga apabila semakin rendah penambahan glukosa dan sukrosa maka nilai kadar protein semakin tinggi pula. Hal ini sesuai dengan pernyataan Yuliati et al. (2018) bahwa semakin tinggi kosentrasi rumput laut maka kadar protein semakin tinggi. Selanjutnya perlakuan perbandingan kosentrasi glukosa 45\% dan sukrosa 0\% (P1) didapatkan nilai terendah dengan nilai sebesar $3,75 \%$. Rendahnya kadar protein disebabkan karena rumput laut mengalami degradasi saat pemasakaan sebelum penambahan glukosa dan sukrosa sehingga tidak ada bahan baku lain yang mengikat kadar protein pada permen jelly, selain itu sifat dari kosentrat protein dari rumput laut kering yang digunakan dalam pembuatan permen jelly yang dipengaruhi oleh adanya proses pengeringan dan pengaruh panas serta dehidrasi osmotik dapat menyebabkan denaturasi protein. Denaturasi protein oleh panas akan mengubah struktur protein dan dapat mengkerutkan bahan. Hasil tersebut sesuai dengan pernyataan Damayanthy dan Eddy (1995) bahwa proses pemanasan akan menyebabkan protein mengalami degradasi dan keadaan ini tidak hanya menyebabkan penurunan nilai gizinya tetapi aktivitas protein sebagai enzim dan hormon akan hilang. Berdasarkan uji fitokimia bahan dasar pada rumput laut ( $E$. cottonii) yang digunakan dalam pembuatan permen jelly menunjukkan adanya senyawa alkaloid dan saponin, maka diduga dari hal tersebut saponin dan alkaloid larut dalam kadar air dan mengikat kadar protein permen jelly. Hal ini didukung oleh pernyataan Hadiwiyoto (1993) bahwa semakin tinggi kadar air dari suatu bahan pangan yang dihasilkan maka kadar protein akan semakin rendah karena miogen dan protein larut dalam air begitu sebaliknya.

\section{KESIMPULAN}

Berdasarkan hasil dan pembahasan, maka dapat disimpulkan sebagai berikut :

1. Kosentrasi glukosa dan sukrosa berpengaruh nyata terhadap warna, tekstur dan rasa permen jelly rumput laut namun berpengaruh tidak nyata terhadap aroma. Perlakuan terbaik terdapat pada perlakuan P4 dengan nilai warna sebesar 4,5 dengan kategori sangat suka, tekstur 4,2 dengan kategori suka, aroma 4,0 dengan kategori suka dan rasa 4,2 dengan kategori suka.

2. Nilai kimia permen jelly rumput laut yaitu nilai kadar air berkisar $17.01 \%-22.83 \%$, kadar abu berkisar 0,11-0.18\% dan kadar protein berkisar $3,75 \%-5.77 \%$.

\section{DAFTAR PUSTAKA}

AOAC. 1995. Official Methods of Analysis of The Association of Official Agriculture Chemist. Inc. Washington DC. P. 185-189

AOAC. 2005. Official Methods of Analysis of The Association of Official Agriculture Chemist 16th Edition. Virginia.

BPS. 2016. Produksi Rumput Laut Menurut Kabupaten Kota Di Provinsi Ntt. Cited In Https://Ntt.Bps.Go.Id/Dynamictable/2018/02/ 09/629/Produksi-Rumput-Laut-MenurutKabupaten-Kota-Di-Provinsi-Nusa-

Tenggara-Timur-2011-2016. Html. [31 Juli 2018].

Damayanthi E dan Eddy. 1995. Teknologi Makanan. Departemen Pendidikan Dan Kebudayaan. Dikdasmen. Jakarta

Departemen Kelautan Dan Perikanan (DKP). 2006.

Pedoman Umum Kelembagaan Tempat

Pelelangan Ikan. Direktorat Pemasaran

Dalam Negeri. Direktorat Jenderal

Pengolahan Dan Pemasaran Hasil 
Perikanan. Jakarta: Departemen Kelautan Dan Perikanan Republik Indonesia

Ferdin. Tamrin, dan Suwarjoyowirayatno. 2019. Formulasi Dan Karakterisasi Permen Jelly Dari Buah Pala Dan Rumput Laut. J. Sains Dan Teknologi Pangan. 4 (3) : 2231-2240

Hadiwiyoto S. 1993. Teknologi Pengolahan Hasil Perikanan. Penerbit Liberty : Yogyakarta

Hakim M. S. 2000. Karakteristik Karamel Susu Dengan Penambahan Kacang Kedelai (Glycine Max (L) Merrill). [Skripsi]. Jurusan IImu Produksi Ternak, Institut Pertanian Bogor. Bogor. $68 \mathrm{HIm}$.

Harborne, J. B. 1987. Metode Fitokimia. Penuntun Cara Modern Menganalisis Tumbuhan. Alih bahasa Kosasih Padmawinata. ITB Bandung. Hal 1-107

Idham P. N., Isamu T. K., dan Suwarjoyowirayatno. 2018. Analisis Organoleptik Dan Kandungan Kimia Permen Jelly Anggur Laut (Caulerpa Racemosa). J. Fish Protech 2018, Vol. 1 No. 2 Http:// Ojs. UHO.Ac.Id/ Index.Php/Jfp

Jumri, Yusmarini, dan Netti H. 2015. Mutu Permen Jelly Buah Naga Merah (Hylocereus Polyrhizus) Dengan Penambahan Karagenan Dan Gum Arab. Jom Faperta. Vol: 2 (1).

Khordi. 2010. Penelitian Pembuatan Karaginan Dari Rumput Laut Eucheuma Cottonii Di Wilayah Perairan Kabupaten Jeneponto Propinsi Sulawesi Selatan. Makassar:Universitas Hasanudin.

Khunaifi, M. 2010. Uji Aktivitas Antibakteri Ekstrak Daun Binahong (Anredera cordifolia (Ten.) Steenis) terhadap Bakteri Staphylococcus aureus dan Pseudomonas aeruginosa. Skripsi. Jurusan Biologi Fakultas Sains dan Teknologi Universitas Islam Negeri Maulana Malik Ibrahim Malang.

Lestariani I. 2008. Pengaruh konsentrasi Sukrosa Dengan Glukosa dan konsentrasi Gelatin Terhadap Karakteristik Soft Candy Mix Fruit Sirsak dan Mangga Kweni. [Skripsi]. Universitas Pasundan, Bandung.

Mandei H. J. 2014. Komposisi Beberapa Senyawa Gula Dalam Pembuatan Permen Keras Dari Buah Pala Composition Of Several Sugar Compounds In The Making Of Nutmeg Hard
Candy. Issn No:2085-580x1. Jurnal Penelitian Teknologi Industri. 6 (1) 1-10

Mayore, S., Lena J. D., Hanny, W.M., Netty, S., Grace, S. dan Daisy, M.M. 2018. Analisis Fitokimia dan Uji Total Kapang Pada Rumput Laut Kering Eucheuma denticulatum dan Kappaphycus alvarezii. Jurnal Media Teknologi Hasil Perikanan Vol. 6 No.3.

Meyer, B.N., N.R. Ferrigni, Putnam, J.E., Jacobsen, L.B., Nichols, D.E., McLaughlin J.L. 1982. Brine Shrimp : A Convenient General Bioassay for Active Plant Constituents. Planta Medica ; 45: 31-34.

Nuria, M. C., Faizaitun, A., Sumantri. 2009. Uji Aktivitas Antibakteri Ekstrak Etanol Daun Jarak Pagar (Jatropha Curcas L) Terhadap Bakteri Staphylococcus Aureus ATCC 25923, Escherichia Coli ATCC, Dan Salmonella Typhi ATCC 1408, Mediagro, 5 (2) : 26-37

Nurwati. Formulasi hard candy dengan penambahan ekstrak buah pedada (Sonneratia caseolaris) sebagai flavor. Institut Pertanian Bogor; 2011.

Panggalih A. I. 2010. Pengaruh Jenis Kemasan Dan Suhu Penyimpanan Pada Umur Simpan Teh Hijau. [Skripsi]. Bogor: Institut Pertanian Bogor

Putri S. M. R., Ninsix R., Dan Sari G. A. 2015. Pengaruh Jenis Gula Yang Berbeda Terhadap Mutu Permen Jelly Rumput Laut (Eucheuma Cottonii) Jurnal Teknologi Pertanian Andalas. Vol 19. No.1.

Rahmi, Tafzi F., dan Anggraini S. 2012. Pengaruh Penambahan Gelatin Terhadap Pembuatan Permen Jelly Dari Bunga Rosella (Hibiscus Sabdariffa Linn). Jurnal Penelitian Universitas Jambi Seri Sains. 14 (1): 37-44

Rofiah A. dan Machfudz A. 2014. Kajian Dosis Sukrosa Dan Sirup Glukosa Terhadap Kualitas Permen Karamel Susu.11 (1) : 55.

Salamah E., Erungan A. C., dan Retnowati Y. 2006.

Pemanfaatan Gracilaria Sp. Dalam

Pembuatan Permen Jelly. Jurnal Pengolahan Hasil Perikanan Indonesia. 9 (1): $38-46$

SNI 2346 : 2011. Petunjuk Organoleptik dan atau Sensori pada Produk Perikanan. Badan Standarisasi Nasional. Jakarta. 
SNI 3547. 2. 2008. Syarat Mutu Kembang Gula Lunak. Badan Standarisasi Nasional. Jakarta.

Sari, PP., Rita W.S., dan Puspawati N.M. 2015. Identifikasi dan Uji Aktivitas Senyawa Tanin dari Ekstrak Daun Trembesi (Samanea saman, Jacq Merr) sebagai Antibakteri Escherichia coli. Jurnal Kimia 9 (1): 27-34.

Sastrohmidjojo H. 1996. Sintesis Bahan Alam. Gajahmada University Press : Jogjakarta

Supriyanto, Simon B. W., Rifa'i M., dan Yunianta. Uji Fitokimia Dan Aktivitas Antioksidan Ekstrak Daun Mimba (Azaradiracta Indica Juss). Prosiding Snatif Ke-4 Tahun 2017

Winarno F.G. 1997. Pangan, Enzim Dan Konsumen. Gramedia Pustaka Utama. Jakarta

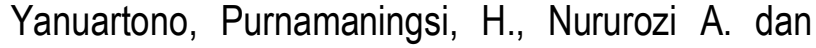
Indarjulianto S. (2017). Jurnal Peternakan Sriwijaya. 6 (2) : 79 - 90.

Yuniarti A. 2011. Kadar Zat Besi, Serat, Gula Total, Dan Daya Terima Permen Jelly Dengan Penambahan Rumput Laut Gracilaria Sp Dan
Sargassum Sp. Program Studi IImu Gizi. Fakultas Kedokteran Universitas Diponegoro. Semarang

Yunizal. 1999. Teknologi Ekstraksi Alginat Dari Rumput Laut Coklat (Phaeophyceae). Instalasi Penelitian Perikanan Laut Slipi, Balai Penelitian Perikanan Laut, Pusat Penelitian Dan Pengembangan Perikanan. Jakarta.

Yuliati, Sari I. N., Dan Loekman. 2018. Studi Penerimaan Konsumen Terhadap Permen Jellyrumput Laut (Eucheuma Cottonii) Dengan Penambahan Pewarna Alami Rosela(Hibiscus Sabdariffa L). Fakultas Perikanan Dan IImu Kelautan. Universitas Riau

Xiren and Aminah. 2014. Elimination of seaweed odour and its effect on antioxidant activity. Department of Food science, School of Chemical Sciences and Food Technology. University Kebangsaan Malaysia, 43600 Bangi, Selangor. Malaysia. 